\title{
Partial Defoliation Stimulates Growth of Arizona Cottontop
}

\author{
DWIGHT R. CABLE
}

\begin{abstract}
Responses of Arizona cottontop to partial defoliation were determined by removal of the terminal growing point in the latter half of July of basal culms that were in various stages of development at the time. If soil moisture was available cottontop responded well to grazing throughout its growing season. Removal of the growing point stimulated axillary shoot growth regardless of the stage of development.
\end{abstract}

Responses of range grasses to grazing, or partial defoliation, differ among species. Grazing systems, therefore, should be designed to take advantage of the after-grazing growth responses of the major species.

Arizona cottontop (Trichachne californica (Benth.) Chase) ${ }^{1}$ is an especially valuable perennial grass on southwestern ranges, because of its highly developed ability to use soil moisture at any time during the growing season: to initiate and grow new shoots, to develop and mature inflorescences, and to thrive under relatively heavy use (up to 55 or $60 \%$ ) (Cable 1979). This study on Arizona cottontop was designed to determine how removal of the growing point affects subsequent regrowth. Removal of the growing point was done to simulate partial defoliation by grazing.

Low resistance to grazing in perennial grasses has been associated with early elevation of the growing point and with a high ratio of reproductive to vegetative shoots (Branson 1953, Rechenthin 1956). Previous work, however, suggests that Arizona cottontop is very resistant to grazing even though it possesses both of these "low resistance" characteristics (Cable 1971, 1979).

Unlike those of many grasses, culms of Arizona cottontop do not die back to the ground each year. Instead, individual basal culms of Arizona cottontop may live 3 years or more and can produce up to eight mature axillary shoots during their lifetime (Cable 1971). Typically, elongation of a basal shoot begins in the spring and is completed in the summer of the same year. Axillary shoots can originate during any growing period on either intact or grazed shoots, and inflorescences can mature almost throughout the summer. In southern Arizona the spring and summer growing periods are separated by a drought-induced period of dormancy in May and June. It is not surprising that Arizona cottontop with its perennial, branching culms, and extreme flexibility in time of shoot and fruit development, should respond differently than grasses whose culms are initiated only during a single short period of the growing season.

\section{Study Area}

This study was conducted during the summer of 1970 on the Santa Rita Experimental Range, about $50 \mathrm{~km}$ south of Tucson, Ariz., at an elevation of $1043 \mathrm{~m}$. Annual precipitation averages $32.2 \mathrm{~cm}$, with about $56 \%$ falling during the July-September summer growing period. In 1970 summer rainfall was $44 \%$ above

\footnotetext{
Author, now retired, was principal range scientist, Rocky Mountain Forest and Range Exp. Sta., U.S. Dep. Agr. Forest Service, Research Work Unit at Tucson, in cooperation with University of Arizona. Station headquarters is in Fort Collins, in cooperation with Colorado State University.

Manuscript received September $25,1980$.
}

1'Referred to by Gould (1968) as Digitaria californica. average. Soil at the study site is a gravelly sandy loam. Arizona cottontop was the dominant perennial grass, with smaller a mounts of three-awn (Aristida spp.), bush muhly (Muhlenbergia porteri), and plains bristlegrass (Setaria macrostachya). Plants of the halfshrub burroweed (Aplopappus tenuisectus) were scattered on the study area, with occasional trees of velvet mesquite (Prosopis juliflora var. velutina).

\section{Methods}

Replicate pairs of similar culms at six stages of development were selected and tagged on each of 16 medium-size, healthy, field-grown plants during the last half of July 1970 (most on July 15). In a few instances, all developmental stages were not present on the selected plants, and additional pairs of culms were tagged on nearby plants. The growing point was removed from one culm of each pair and the length of all axillary shoots on each culm, from the collar of the enclosing leaf sheath to the tip, were measured weekly for the next 11 weeks. The six stages of development and culm heights at time of tagging were (Fig. 1):

1. Vegetative-Growing point in vegetative condition. Shoots averaged about $174 \mathrm{~mm}$ overall. In removing growing points, the culms were severed through the topmost elongated internode, just below the collar of the third fully expanded leaf blade.

2. Early Reproductive-Panicles mostly less than $2 \mathrm{~mm}$ long at tagging, with some up to $5 \mathrm{~mm}$. Shoots averaged about $200 \mathrm{~mm}$ overall. Treated culms severed through the topmost rapidly elon-

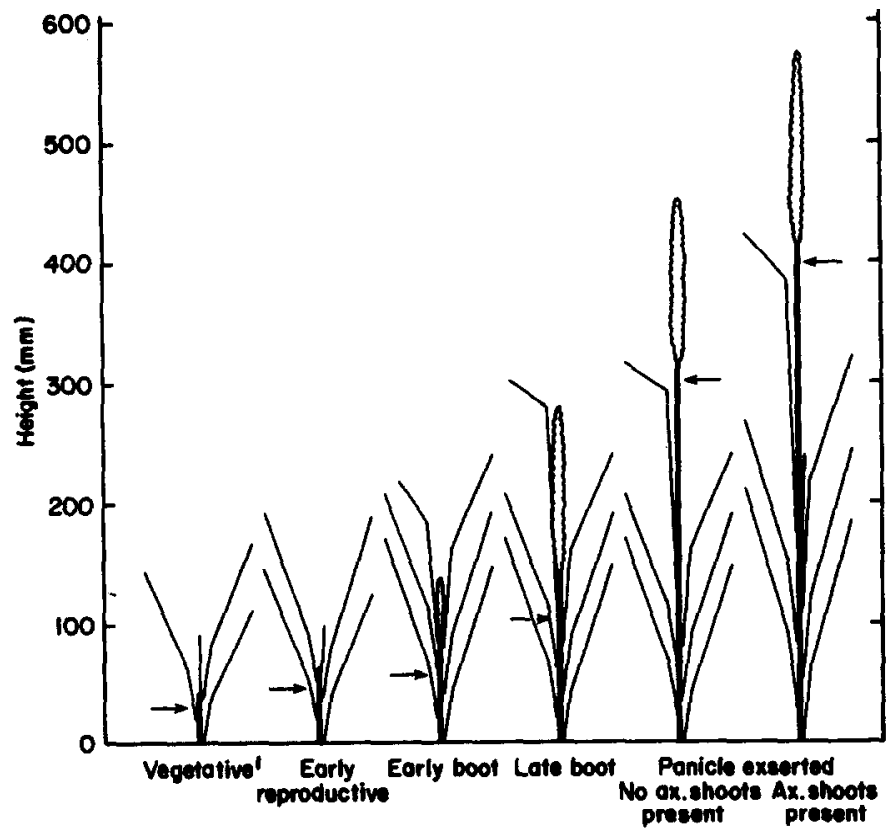

Fig .1. Arizona cottontop culms in six stages of development (arrows indicate where treated culms were severed). In the vegetative stage, uppermost (rolled) leaf is leaf number 5; 4 shorter leaves surround the vegetative growing point. In the early reproductive stage, uppermost (rolled) leaf is leaf number 5; 4 shorter leaves surround the short panicle. 
growing season. A notable exception is the group of culms tagged at the exserted-no axillary shoots present stage. Control culms in this group produced no more axillary shoot growth than vegetative control culms; treated culms in this group, however, produced about twice the axillary shoot growth as the vegetative treated culms, but only about half as much as the early boot, and exsertedaxillary shoots present treated culms (Fig. 3).

As measured at the end of the growing season, the greatest gain in axillary shoot growth caused by removing the growing points, was produced on exserted-no axilla ry shoots present culms (232\% more than control culms). Late boot treated culms, at the other extreme, produced only $3 \%$ more axillary shoot growth than their control. Culms with growing points excised at other growth stages produced from $15 \%$ to $68 \%$ more axillary shoot growth than their respective controls (Fig. 3). Differences between treated and control culms in total length of axillary shoots at the end of the growing season were significant $(P=0.05)$ for all stages except late boot and exserted-axillary shoots present.

Second-order axillary shoots began appearing within 4 weeks after tagging on culms with exserted seed heads. Second-order shoots appeared increasingly later on culms tagged at earlier stages of development, during the tenth week for early reproductive and vegetative culms.

The likelihood of a given axillary bud sprouting was strongly related to its position on the culm. For both treated and control culms, $53 \%$ of axillary shoots originated from the topmost bud (Fig. 4). Second-order axillary shoots were more numerous (33\%
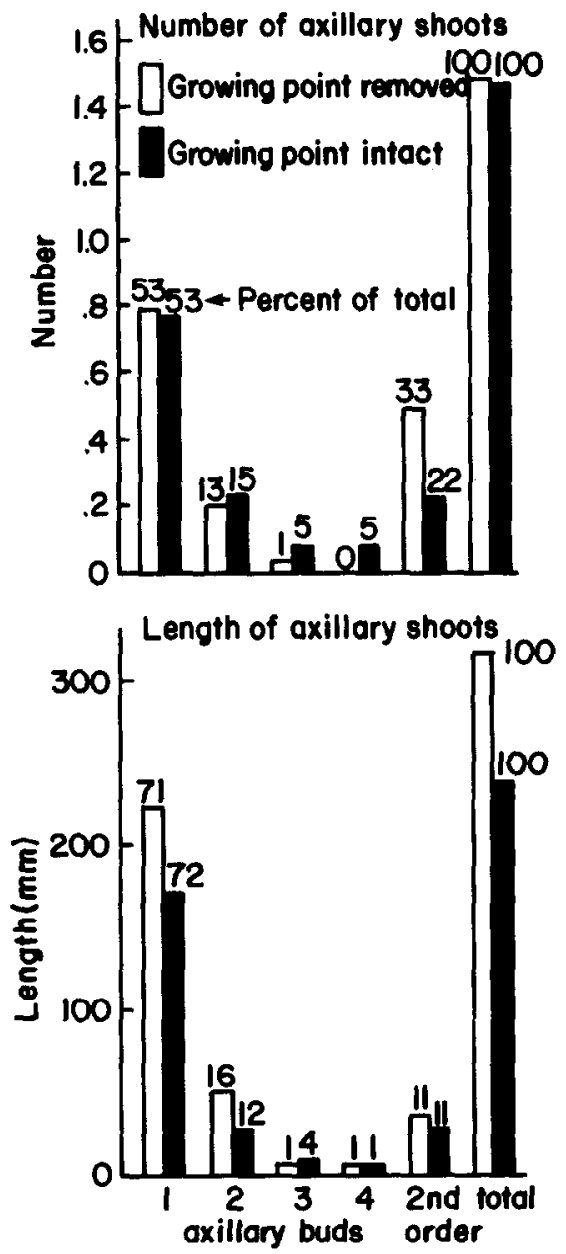

Fig. 4. Numbers and total length of axillary shoots per culm, arising from different axillary buds on treated and control culms by the end of the study period $(1=$ uppermost bud on culm; 2 nd order $=$ shoots from buds on first-order axillary shoots). Numbers are averaged across growth stages. and $22 \%$ of the total) than were shoots from the $2 \mathrm{nd}, 3 \mathrm{rd}$, and 4 th axillary buds on treated and control culms, respectively. Of these second-order shoots, $86 \%$ were on shoots originating from topmost buds. Differences between treated and control culms in numbers of axillary shoots for individual bud locations were not significant.

The growth of axillary shoots was even more strongly associated with position on the culm than were number of culms. For both treated and control culms, slightly more than $70 \%$ of total axillary shoot length was produced on shoots from topmost buds (Fig. 4). Percentages in Figure 4 agree closely with data obtained in other studies (Cable 1971).

\section{Conclusions and Management Implications}

Arizona cottontop produces axillary sprouts from culm buds as a normal part of its seasonal growth and development, whether or not the growing point is intact. However, removing the growing point from the culms in certain stages of development (e.g., vegetative, early reproductive, exserted-no axillary shoots) greatly speeds up the rate of appearance and growth of axillary shoots early in the growing season, and results in significantly more total seasonal growth of axillary shoots. This stimulation of axillary sprout growth has been recognized as an indicator of the ability of a grass to persist under heavy or continuous grazing (Dahl and Hyder 1977). It also suggests that Arizona cottontop produces more and better forage under moderate grazing than under no grazing.

The development of as many axillary shoots on intact as on treated culms during the 1970 summer growing season (Fig. 4) demonstrated cottontop's weak apical dominance. Apical dominance was most pronounced early in the summer and decreased to near zero later (Fig. 2). Weak apical dominance is a valuable characteristic for range grasses because it permits the development of axillary shoots without removal of the growing point (partial defoliation), thereby increasing herbage production compared to that of species with strong apical dominance.

All six stages of development are typically present on any given cottontop plant at any given time in the growing season. As a consequence, there is no time during the growing season when cottontop is especially harmed by grazing. Also, if soil moisture is available, cottontop's ability to recover is relatively high and uniform throughout the growing season.

Two important management implications can be derived from the data presented and other data cited:

1. Cottontop's highly developed ability to make use of soil moisture whenever it is available to: (a) initiate and grow new shoots, and (b) develop and mature inflorescences, make it highly tolerant to grazing.

2. Cottontop's growth habit, in which shoots in all stages of development are present throughout most of the growing season, its ability to produce axillary shoots from culms in all stages of development, and the fact that axillary shoot growth is stimulated by removal of the growing point, regardless of stage of development, suggest that cottontop will thrive under grazing at any season, if use does not exceed 55 to $60 \%$ (Cable 1979). There is no strongly "most vulnerable" time of year for Arizona cottontop.

\section{Literature Cited}

Branson, Farrel A. 1953. Two new factors affecting resistance of grasses to grazing. J. Range Manage. 6:165-171.

Cable, Dwight R. 1971. Growth and development of Arizona cottontop (Trichachne californica (Benth.) Chase). Bot. Gaz. 132:119-145.

Cable, Dwight R. 1979. Ecology of Arizona cottontop. USDA Forest Serv., Res. Pap. RM-209, 21 p. Rocky Mt. Forest and Range Exp. Sta., Fort Collins, Colo.

Dahl, B.E., and D.N. Hyder. 1977. Developmental morphology and management implications. p. 257-290. In: Rangeland plant physiol. Range Sci. Ser. 4. Soc. Range Manage. Denver, Colo.

Rechenthin, C.A. 1956. Elementary morphology of grass growth and how it affects utilization. J. Range Manage. 9:167-170. 